\title{
Pengaruh Pembelajaran Daring di Era Pandemi Covid-19 Terhadap Motivasi dan Kepuasan Belajar Taruna/i Jurusan Teknika STIP Jakarta
}

\author{
Diah Zakiah $^{1}$, Yuni Mariah ${ }^{2}$ \\ 1, 2 Jurusan Teknika, Sekolah Tinggi Ilmu Pelayaran, Jakarta \\ Jl. Marunda Makmur No. 1 Cilincing, Jakarta Utara. Jakarta 14150
}

\begin{abstract}
Abstrak
Pandemi Covid-19 telah mendorong semua sektor kehidupan beradaptasi untuk mencegah meluasnya wabah. Sektor pendidikan termasuk yang terkena dampak, dimana tatap muka di kelas ditiadakan dan seluruh pembelajaran dialihkan ke dalam jaringan. Perubahan metode pembelajaran ini tentu sangat berpengaruh terhadap motivasi belajar dan kepuasan menerima pembelajaran. STIP Jakarta sebagai lembaga pendidikan tinggi vokasi di era pandemi telah melaksanakan pembelajaran dalam jaringan (daring) terhitung sejak tanggal 23 Maret 2020 hingga akhir masa perkuliahan semester genap tahun ajaran 2019/2020. Penelitian ini dilakukan dengan melakukan jajak pendapat kepada Tarun/i Jurusan Teknika mengenai motivasi belajar dan tingkat kepuasan terhadap pelaksanaan pembelajaran daring
\end{abstract}

Copyright (C) 2020, Prosiding Seminar Pelayaran dan Riset Terapan

Kata Kunci : pembelajaran daring, covid-19, motivasi, kepuasan, taruna

\section{PENDAHULAN}

Pandemi Covid-19 yang berawal di kota Wuhan, provinsi Hubei, China di awal tahun 2020, dalam beberapa pekan sudah meluas ke seluruh dunia. Saat laporan ini ditulis Covid19 telah menyebar di 214 negara, menjangkiti lebih dari 14 juta orang, 8,6 juta diantaranya berhasil sembuh dan 605 ribu diantaranya meninggal.

Di Indonesia data resmi pertama kasus covid-19 diumumkan tanggal 02 Maret 2020. Dua kasus pertama, seorang ibu dan anaknya yang sempat melakukan kontak dengan warga negara Jepang yang baru terdeteksi covid-19 di Malaysia setelah meninggalkan Indonesia. Jumlah kasus di Indonesia masih terus bertambah hingga saat ini, bahkan telah melampaui jumlah kasus di China. Lebih dari 45 ribu orang berhasil sembuh, namun empat ribu-an orang meninggal dunia karena penyakit ini.

Gejala umum Covid-19 adalah demam, batuk kering dan rasa lelah. Sebagian orang hanya mengalami gejala ringan bahkan ada yang tidak merasakan gejala sama sekali. Sekitar $80 \%$ penderita dapat sembuh tanpa perawatan khusus. Pada 20\% kasus sisanya, penderita mengalami kesulitan bernafas sehingga harus dirawat intensif, dan sekitar 4\% diantaranya berakhir dengan kematian. Penyakit ini menyebar melalui droplet atau percikan dari hidung atau mulut yang keluar dari orang yang terinfeksi Covid-19 saat orang tersebut batuk, bersin dan berbicara. Selain dengan menghirup langsung, penularan juga dapat terjadi dari percikan yang menempel di benda yang umum disentuh, seperti pegangan pintu dan tombol lift, bila tangan yang menyentuhnya kemudian menyentuh muka, hidung atau mulut. Untuk itu penting untuk menjaga jarak minimal 1 meter dari orang lain dan rutin mencuci tangan dengan air dan sabun setelah menyentuh benda-benda di tempat umum.

Untuk mencegah penyebaran Covid-19 Kementerian Kesehatan menerbitkan Peraturan Menteri no 9 tahun 2020 mengenai Pedoman Pembatasan Sosial Berskala Besar (PSBB), untuk membatasi kegiatan penduduk di suatu wilayah yang terjangkit wabah Covid19.

Di sektor pendidikan, beberapa lembaga Pendidikan Tinggi berinisiatif meniadakan tatap muka mulai pertengahan Maret 2020. STIP Jakarta merupakan perguruan tinggi yang menyelenggarakan pendidikan Vokasi dengan sistem boarding, dimana taruna tinggal di dalam asrama. STIP mulai melaksanakan 
pembelajaran dalam jaringan (daring) sejak 23 Maret 2020 tepatnya pekan kedua di masa perkuliahan semester genap tahun ajaran 2019/2020 dan berlangsung hingga masa perkuliahan berakhir di semester tersebut.

Yang menjadi permasalahan dalam pembelajaran daring dalam situasi wabah Covid-19 ini adalah metode pembelajaran, kedua motivasi taruna serta dampaknya terhadap tingkat efektivitas pembelajaran atau kepuasan belajar.

Metode Pembelajaran atau Model Pembelajaran adalah seluruh rangkaian penyajian materi ajar yang meliputi segala aspek sebelum sedang dan sesudah pembelajaran yang dilakukan guru juga segala fasilitas yang terkait yang digunakan secara langsung atau tidak langsung dalam proses belajar mengajar. Sedangkan metode pembelajaran daring berarti secara prinsip sama hanya saja dilakukan melalui jarak jauh atau menggunakan media elektronik baik melalui videocall, telecomference, whattaps, email, dan lain-lain. Dalam prakteknya tentunya metode pembelajaran ini akan mempengaruhi taruna yakni dari aspek motivasi dan tingkat efektivitas pembelajaran.

Berdasarkan uraian di atas, maka yang menjadi masalah yang dikaji dalam penelitian ini adalah (1) Bagaimana efektifitas metode pembelajaran dalam jaringan (2) Bagaimana pengaruh metode pembelajaran dalam jaringan terhadap motivasi belajar taruna ?; dan (3) Bagaimana pengaruh metode pembelajaran dalam jaringan terhadap kepuasan belajar taruna?

Berdasarkan penjelasan masalah yang telah diuraikan,maka tujuan pada penelitian ini adalah (1) Untuk mengetahui efektifitas metode pembelajaran dalam jaringan; (2) Untuk mengetahui pengaruh metode pembelajaran dalam jaringan terhadap motivasi belajar taruna; dan (3) Untuk mengetahui pengaruh metode pembelajaran dalam jaringan terhadap kepuasan belajar taruna.

Penelitian ini diharapkan dapat memberikan manfaat dan informasi yang dapat digunakan oleh berbagai pihak yang membutuhkan.
(1) Manfaat Teoritis, hasil penelitian ini diharapkan dapat menjadi sarana informasi dan referensi untuk mengevaluasi metode pembelajaran dalam jaringan.

(2) Manfaat Praktis, dari hasil penelitian ini diharapkan dapat memberikan manfaat bagi institusi perguruan tinggi dalam meningkatkan mutu pendidikan berdasarkan hasil riset terhadap tingkat motivasi dan kepuasan belajar taruna.

\section{TINJAUAN UMUM TENTANG PEMBELAJARAN ONLINE}

\subsection{Pembelajaran Online (E-learning)}

E-learning adalah pembelajaran yang memungkinkan atau didukung oleh penggunaan alat dan konten digital. E-learning biasanya melibatkan beberapa bentuk interaktivitas, termasuk di dalamnya dapat berupa interaksi online antara peserta didik dan pengajar atau kelompok mereka. Elearning biasanya diakses melalui internet, namun teknologi lainnya seperti CD-ROM juga dapat digunakan. Walaupun demikian, penggunaan istilah pembelajaran online lebih identik dengan pembelajaran melalui internet atau jaringan.

Mengapa pembelajaran online perlu dilakukan? Untuk membahas hal tersebut lebih dalam, penulis akan memaparkan beberapa butir studi literatur yang perlu diketahui; yaitu aspek personal pembelajar, personalisasi pembelajaran, dan kelebihan pembelajaran online.

\subsection{Aspek Personal Pembelajar}

Proses belajar-mengajar menurut Huitt memiliki berbagai komponen yang berpengaruh, seperti komunitas (ukuran dan wilayah); keluarga (tingkat pendidikan ibu, pendapatan keluarga, buku-buku yang ada di rumah, serta ekspektasi akademik); pengajar yang terdiri dari aspek karakteristik pengajar dan aktivitas/tingkah laku pengajar; pembelajar yang terdiri dari dari aspek karakteristik pembelajar dan aktivitas/tingkah laku pembelajar; kebijakan sekolah; serta kebijakan negara. Gaya belajar dan prior kowledge merupakan bagian dari karakteristik 
pembelajar, selain kecerdasan dan motivasi yang akan mempengaruhi aktivitas pembelajar dalam proses belajar-mengajar.

\subsubsection{Gaya Belajar dalam Pembelajaran}

Proses belajar mengajar memiliki sejumlah tujuan yang ingin dicapai. Berdasarkan tujuan-tujuan tersebut, semua kegiatan dirancang untuk memfasilitasi peserta didik dalam memperoleh pengetahuan dan keahlian. Dalam proses tersebut seringkali diasumsikan bahwa peserta didik memiliki gaya belajar (learning style) yang sama. Padahal dalam realitasnya tidaklah selalu demikian. Pada beberapa penelitian yang telah dilakukan sebelumnya, terungkap bahwa pengabaian terhadap gaya belajar peserta didik yang berbeda tersebut justru tidak memfasilitasi peserta didik dalam mengoptimalkan potensi yang dimiliki dalam belajar. Gaya belajar merupakan pendekatan dalam pembelajaran yang menekankan fakta bahwa individu-individu menerima dan memproses informasi dengan cara-cara yang sangat berbeda.

Setidaknya terdapat empat model gaya belajar yang telah dikembangkan saat ini, antara lain:

a. The Myers-Briggs Type Indicator (MBTI),

b. Kolb's Learning Style Model,

c. Herrmann Brain Dominance Instrument (HBDI), dan

d. Felder-Silverman Learning Style Model.

Berikut ini akan dijelaskan mengenai Felder-Silverman Learning Style Model yang akan digunakan pada penelitian ini. Model lainnya tidak dijelaskan karena tidak digunakan dan beberapa penjelasan akan beririsan dengan model Felder-Silverman.

Felder-Silverman Learning Style Model membagi gaya belajar berdasarkan lima dimensi. Gaya belajar tersebut terdiri dari gaya belajar active-reflective, gaya belajar inductive-deductive, gaya belajar visualverbal, gaya belajar sensing-intuitive, dan gaya belajar sequential-global.

a. Gaya Belajar Active-Reflective (Dimensi Pemrosesan)

Pembelajar dengan gaya belajar active cenderung untuk memelihara dan memahami informasi yang terbaik dengan melakukan keaktifan dengannya membahas, menerapkannya, atau menj elaskannya kepada orang lain. Di lain sisi, pembelajar reflective memilih untuk memikirkannya dahulu dengan tenang. Sebuah ungkapan dari pembelajar active adalah, "Mari mencobanya dan lihat bagaimana ia bekerja", sedangkan pembelajar reflective berkata, "Mari kita pikirkan terlebih dahulu". Pembelajar active lebih menyukai belajar kelompok, sebaliknya pembelajar reflective lebih menyukai belajar sendiri. Mendengarkan ceramah tanpa melakukan kegiatan fisik kecuali menulis catatan sulit dilakukan keduanya, namun khususnya bagi pembelajar active.

b. Gaya Belajar Sensing-Intuitive (Dimensi Persepsi)

Pembelajar bertipe sensing cenderung menyukai mempelajari fakta, sedangkan pembelajar bertipe intuitive sering kali lebih memilih menemukan kemungkinan dan hubungan. Sensor lebih mudah memahami jika diberikan contoh dari konsep dan prosedur dan menemukan bagaimana konsep diaplikasikan pada praktik; sedangkan pembelajar intuitive mencoba memahami suatu interpretasi atau teori yang menghubungkan fakta. Oleh karena itu, sensor cocok diberi pengajaran dengan aplikasi nyata, sedangkan pembelajar intuitive cocok diberikan peta konsep.

c. Gaya Belajar Visual-Verbal (Dimensi Input)

Pembelajar visual mengingat apa yang dilihatnya dengan baik, seperti gambar, diagram, time line, film, atau demonstrasi; sedangkan pembelajar verbal lebih banyak mendapat informasi dari kata-kata dan penjelasan terucap sehingga mereka menyukai diskusi dan proyek tulisan.

d. Gaya Belajar Sequential-Global (Dimensi Pemahaman)

Pembelajar sequential memperoleh pemahaman melalui langkah-langkah linear. Pembelajar global berusaha memahami gambaran besar dan memecahkan masalah kompleks sekali 
ketika mendapatkan gambaran besar.
e. Gaya Belajar Inductive-Deductive
(Dimensi Organisasi)

Pembelajar inductive memproses informasi dari yang spesifik ke general, sedangkan pembelajar deductive sebaliknya.

\subsubsection{Prior Knowledge dalam Pembelajaran}

Dalam The Strategic Teaching and Reading Project Guidebook, disebutkan prior knowledge dapat dijelaskan sebagai kombinasi dari sikap pembelajar yang telah ada sebelumnya, pengalaman-pengalaman, dan pengetahuan mereka. Alice Moses mengatakan siswa belajar lebih efektif ketika mereka sudah mengetahui sesuatu tentang sebuah area konten serta bila konsep-konsep di dalam area tersebut memiliki suatu makna bagi mereka dan bagi latar belakang dan budaya mereka. Jika pengajar menghubungkan informasi baru dengan prior knowledge siswa, mereka mengaktifkan ketertarikan dan rasa ingin tahu siswa, dan memompakan pengajaran dengan makna.

Prior knowledge setiap pembelajar bisa sama, hampir sama, atau bahkan secara signifikan tidak sama. Secara eksplisit, perbedaan prior knowledge di antara pembelajar dapat diketahui melalui pre-test yang dilakukan sebelum pembahasan materi inti. Bila pengajar dalam mengajar menggunakan tempo stabil saja, maka pembelajar yang memiliki prior knowledge sedikit atau tidak sejalan, kemungkinan besar ia akan gagal.

\subsection{Kelebihan Pembelajaran Online}

Implementasi konsep personalisasi pembelajaran dalam konteks pembelajaran konvensional ternyata sulit dilakukan. Hal ini disebabkan beragamnya gaya belajar maupun prior knowledge serta kecerdasan yang dimiliki pembelajar. Sementara di sisi lain, pengajar hanya menerapkan satu tipe metode pembelajaran dalam satu rentang waktu yang paling tidak sesuai dengan satu tipe gaya belajar saja serta menerapkan standar prior knowledge dan kecerdasan yang sama bagi para siswa. Bila hal ini terjadi, maka pembelajar lain yang berbeda gaya belajar akan terabaikan, pembelajar dengan prior knowledge kurang sulit mengikuti, sedangkan dengan prior knowledge dan kecerdasan lebih baik akan meninggalkan mereka yang kurang. Pengajar dapat menyesuaikan dengan standar prior knowledge dan tingkat kecerdasan terendah, tetapi ini tidak efesien serta tidak dapat mengakomodasi siswa yang memiliki kemampuan lebih tinggi. Namun dalam konteks pembelajaran online, personalisasi sangat memungkinkan untuk dilakukan yaitu melakukan serangkaian perlakuan terhadap learning management system dan learning object yang adatif terhadap tipe gaya belajar, prior knowledge, dan tingkat kecerdasan yang beraneka ragam. Personalisasi mampu menghadirkan perlakuan yang berbeda terhadap sejumlah peserta didik dalam rentang waktu bersamaan (paralel).

\section{METODE}

Jenis penelitian ini termasuk penelitian deduktif dengan pendekatan kuantitatif, yakni penelitian untuk meneliti fakta, teoritis dan studi empiris terkait obyek yang hendak diteliti. Populasi dalam penelitian ini adalah Taruna Jurusan Teknika Sekolah Tinggi Ilmu Pelayaran (STIP) Jakarta semester II, IV, VII dan VIII pada semester genap tahun ajaran 2019/2020.

Instrumen penelitian menggunakan model survey dengan menyebarkan kuesioner. Sedangkan metode analisis menggunakan pendekatan statistik.

Variabel Penelitian terdiri atas variabel bebas dan terikat, dimana variabel bebasnya adalah:

a. Metode Pembelajaran dalam Jaringan, dengan indikator (1) Penyampaian bahan ajar oleh dosen; (2) Model penyampaian bahan ajar; (3) Efektivitas penyampaian bahan ajar oleh dosen; dan (4) Tidak banyaknya kendala pembelajaran melalui media daring

b. Motivasi, dengan indikator (1) Keinginan dan dorongan kebutuhan untuk belajar; (2) Harapan dari pembelajaran; (3) Penghargaan atau penilaian dari dosen/kampus; dan (4) Suasana dan kegiatan dalam pembelajaran 
Sedangkan Variabel Terikat pada penelitian ini adalah Kepuasan, dengan Indikator (1) Penilaian hasil belajar; (2) Rasa aman dan nyaman dalam belajar (3) Sarana dan prasarana dalam belajar (4) Tingkat harapan dan layanan yang diterima dari pembelajaran online.

Skala ukur menggunakan skala ordinal, yakni 1 = Sangat Setuju, $2=$ Setuju, $3=$ Netral, 4 = Tidak Setuju, 5 = Sangat Tidak Setuju. Metode penelitian ini menggunakan teknik analisis statistik deskriptif.

\section{HASIL DAN PEMBAHASAN}

Penelitian ini dilakukan terhadap Taruna Tingkat I, II dan IV Jurusan Teknika di Sekolah Tinggi Ilmu Pelayaran Jakarta dengan tujuan untuk mengetahui sejauh mana persepsi para taruna tentang pembelajaran melalui daring (online), tingkat motivasi serta pengaruhnya terhadap tingkat kepuasan dalam belajar.

Responden dalam penelitian ini adalah Taruna Jurusan Teknika STIP Jakarta Semester II, IV, VII dan VIII. Pada penelitian ini karakteristik individu yang ditanyakan kepada responden adalah semester dan jenis kelamin.

Tabel 1. Karakteristik Responden

\begin{tabular}{|l|c|c|c|}
\hline Karakteristik & Kategori & Jml & $(\%)$ \\
\hline Semester & II & 104 & $33,3 \%$ \\
\hline & IV & $\mathbf{1 1 7}$ & $\mathbf{3 7 , 5 \%}$ \\
\hline & VII & 24 & $7,7 \%$ \\
\hline & VIII & 67 & $21,5 \%$ \\
\hline Jenis Kelamin & Laki-laki & $\mathbf{3 0 3}$ & $\mathbf{9 7 , 1 \%}$ \\
\hline & Perempuan & 9 & $2,9 \%$ \\
\hline
\end{tabular}

Berdasarkan hasil penelitian dengan menyebarkan angket/kuesioner yang dilakukan pada tanggal 12 Juli 2020 dengan margin error 1\%, maka dari 312 taruna.

\subsection{Metode Pembelajaran melalui Daring}

Dalam variabel metode pembelajaran melalui daring ini ada beberapa indikator yang menjadi penilaian, sebagai berikut: a. Penyampaian bahan ajar oleh dosen

b. Model penyampaian bahan ajar

c. Efektivitas penyampaian bahan ajar oleh dosen

d. Tidak banyaknya kendala pembelajaran melalui media daring

Tabel 2. Ringkasan Tabulasi hasil Kuesioner Variabel Metode Pembelajaran Daring

\begin{tabular}{|l|c|c|c|c|c|}
\hline Variabel Indikator & \multicolumn{5}{|c|}{ Skala Likert } \\
\cline { 2 - 6 } & STS & TS & N & S & SS \\
\hline $\begin{array}{l}\text { Penyampaian bahan } \\
\text { ajar oleh dosen }\end{array}$ & $1,3 \%$ & $7,6 \%$ & $20,5 \%$ & $47,7 \%$ & $23,4 \%$ \\
\hline $\begin{array}{l}\text { Model penyampaian } \\
\text { bahan ajar }\end{array}$ & $1,3 \%$ & $5,2 \%$ & $27,1 \%$ & $45,5 \%$ & $21,5 \%$ \\
\hline $\begin{array}{l}\text { Efektivitas } \\
\text { penyampaian bahan } \\
\text { ajar }\end{array}$ & $1,8 \%$ & $5,2 \%$ & $25,0 \%$ & $38,9 \%$ & $29,4 \%$ \\
\hline $\begin{array}{l}\text { Tidak banyaknya } \\
\text { Kendala } \\
\text { pembelajaran } \\
\text { melalui daring }\end{array}$ & $2,6 \%$ & $13,9 \%$ & $31,3 \%$ & $32,7 \%$ & $19,8 \%$ \\
\hline RATA-RATA & $1,7 \%$ & $7,9 \%$ & $26,0 \%$ & $41,2 \%$ & $23,5 \%$ \\
\hline
\end{tabular}

Berdasarkan tabel 2 di atas, dapat dilihat bahwa penilaian persepsi taruna tentang metode pembelajaran melalui daring yang menjawab sangat tidak setuju (STS) rata-rata berjumlah $1,7 \%$, yang menjawab tidak setuju (TS) 7,9 \%, yang menjawab Netral (N) $26 \%$, yang menjawab setuju (S) 41,2\% dan yang menjawab sangat setuju (SS) $23,5 \%$. Dari sini terlihat sebagian besar taruna, tepatnya $64,7 \%$ setuju dengan metode pembelajaran daring, walaupun masih ada kegamangan di sebagian taruna dalam belajar melalui sistim online, hal ini terlihat 26\% taruna menjawab Netral.

\subsection{Motivasi taruna dalam Pembelajaran melalui Daring}

Dalam variabel motivasi taruna belajar melalui online ini ada beberapa indikator penilaian, sebagai berikut:

a. Keinginan belajar dan dorongan kebutuhan untuk belajar

b. Harapan dari pembelajaran 


\section{c. Penghargaan atau penilaian dari dosen/kampus \\ d. Suasana dan kegiatan dalam pembelajaran}

Tabel 3. Ringkasan Tabulasi hasil Kuesioner Variabel Motivasi Taruna Belajar melalui Online

\begin{tabular}{|l|c|c|c|c|c|}
\hline Variabel Indikator & \multicolumn{5}{|c|}{ Skala Likert } \\
\cline { 2 - 6 } dan & $1,6 \%$ & $5,2 \%$ & $20,7 \%$ & $44,0 \%$ & $28,5 \%$ \\
\hline $\begin{array}{l}\text { Keinginan dari } \\
\text { dorongan kebutuhan } \\
\text { untuk belajar }\end{array}$ & $1,6 \%$ & $5,8 \%$ & $20,8 \%$ & $43,6 \%$ & $28,2 \%$ \\
\hline $\begin{array}{l}\text { Harapan dan } \\
\text { pembelajaran }\end{array}$ & $0,6 \%$ & $1,9 \%$ & $13,5 \%$ & $53,5 \%$ & $30,4 \%$ \\
\hline $\begin{array}{l}\text { Penghargaan atau } \\
\text { penilaian dari dosen/ } \\
\text { kampus dalam }\end{array}$ & $1,9 \%$ & $9,3 \%$ & $31,2 \%$ & $36,3 \%$ & $21,2 \%$ \\
\hline $\begin{array}{l}\text { Suasana } \\
\text { kegiatan } \\
\text { pembelajaran }\end{array}$ & $1,4 \%$ & $5,5 \%$ & $21,5 \%$ & $44,4 \%$ & $27,1 \%$ \\
\hline RATA-RATA & & & & & \\
\hline
\end{tabular}

Berdasarkan tabel 3 di atas, dapat dilihat bahwa penilaian terhadap persepsi taruna tentang motivasi pembelajaran melalui daring yang menjawab sangat tidak setuju (STS) ratarata berjumlah $1,4 \%$, yang menjawab tidak setuju (TS) 5,5\%, yang menjawab Netral (N) 21,5 \%, yang menjawab setuju (S) 44,4 \% dan yang menjawab sangat setuju (SS) 27,1 \%. Disini terlihat motivasi taruna untuk belajar melalui online cukup tinggi.

\subsection{Tingkat Kepuasan Taruna dalam Pembelajaran melalui Daring}

Dalam variabel kepuasan taruna belajar melalui online ini ada beberapa penilaian melalui beberapa indikator, sebagai berikut:

a. Penilaian hasil belajar

b. Rasa aman dan nyaman dalam belajar

c. Sarana dan prasarana dalam belajar

d. Tingkat harapan dan layanan yang diterima dari pembelajaran online
Tabel 4. Ringkasan Tabulasi hasil Kuesioner Variabel Tingkat Kepuasan Taruna Belajar melalui Online

\begin{tabular}{|l|c|c|c|c|c|}
\hline \multirow{2}{*}{$\begin{array}{l}\text { Variabel } \\
\text { Indikator }\end{array}$} & \multicolumn{5}{|c|}{ Skala Likert } \\
\cline { 2 - 6 } & STS & TS & $\mathrm{N}$ & $\mathrm{S}$ & SS \\
\hline $\begin{array}{l}\text { Penilaian hasil } \\
\text { belajar }\end{array}$ & $0,0 \%$ & $2,3 \%$ & $19,7 \%$ & $50,8 \%$ & $27,2 \%$ \\
\hline $\begin{array}{l}\text { Rasa aman dan } \\
\text { nyaman dalam } \\
\text { belajar }\end{array}$ & $0,6 \%$ & $4,5 \%$ & $18,6 \%$ & $44,6 \%$ & $31,7 \%$ \\
\hline $\begin{array}{l}\text { Sarana } \\
\text { prasarana dalam } \\
\text { belajar }\end{array}$ & $1,6 \%$ & $4,5 \%$ & $26,0 \%$ & $42,6 \%$ & $25,3 \%$ \\
\hline $\begin{array}{l}\text { Tingkat harapan } \\
\text { dan layanan } \\
\text { yang diterima } \\
\text { dari } \\
\text { pembelajaran } \\
\text { online }\end{array}$ & $0,6 \%$ & $5,4 \%$ & $24,0 \%$ & $44,2 \%$ & $25,6 \%$ \\
\hline \begin{tabular}{l} 
RATA-RATA \\
\hline
\end{tabular} & $0,7 \%$ & $4,2 \%$ & $22,1 \%$ & $45,6 \%$ & $27,5 \%$ \\
\hline
\end{tabular}

Berdasarkan tabel 4 di atas, dapat dilihat bahwa penilaian terhadap persepsi taruna tentang tingkat kepuasan pembelajaran melalui daring yang menjawab sangat tidak setuju (STS) rata-rata berjumlah $0,7 \%$, yang menjawab tidak setuju (TS) 4,2 \%, yang menjawab Netral (N) 22,1 \%, yang menjawab setuju (S) 45,6 \% dan yang menjawab sangat setuju (SS) $27,5 \%$. Sebagian besar taruna menjawab setuju atau puas yaitu $73,1 \%$, disini terlihat masih ada sedikit ketidakpuasan taruna dalam belajar daring yaitu 4,9\%, dan 22,1\% yang gamang atau ragu.

\section{PENUTUP}

Berdasarkan hasil penelitian ini maka dapat disimpulkan bahwa

1. Sebagian besar taruna menilai metode pembelajaran daring sudah efektif.

2. Dari aspek motivasi para taruna tetap optimis semangat ingin belajar meskipun melalui jaringan

3. Dari penilaian aspek kepuasan secara umum tergambar sudah puas, hanya sedikit yang menyatakan tidak puas, dan sekitar $22 \%$ yang ragu-ragu. 


\section{DAFTAR PUSTAKA}

[1] Juliansyah Noor, 2015. Metode Penelitian, Penerbit Prenada Group, Jakarta

[2] Bangun, Wlison. 2014. Manajemen Sumber Daya Manusia. Alfabeta, Bandung

[3] Sani Supriyanto, Ahmad dan Masyhuri Machfudz. (2016). Metodologi Riset Manajemen Sumber daya Manusia. Malang: UIN Maliki Press

[4] Sugiyono, 2016. Metode Penelitian Kuantitatif, Kualitatif dan R\&D. Bandung: PT Alfabet.

[5] T. Hano Handoko, 2015. Manajemen Personalia dan Sumber Daya Manusia. Yogyakarta. BPFE

[6] Effendi, Empy dan Hartono Zhuang.eLearning Konsep dan Aplikasi. PenerbitAndi, Yogyakarta. 2005

[7] Rohman, Arif. Masalah Pembelajaran dan Pemecahannya. Laporan Seminar Nasional Inovasi Pembelajaran. [Online] available. http://staff.uny.ac.id 